\title{
Foremost Concepts in Mechanisms of De Novo Post-Liver Transplantation Malignancy
}

\author{
Milena Peruhova $^{1}$ (D), Monika Peshevska-Sekulovska ${ }^{1}$, Gabriela Panayotova ${ }^{1}$ and Tsvetelina Velikova $^{2, *(D)}$ \\ 1 Department of Gastroenterology, University Hospital Lozenetz, 1 Kozyak str., 1407 Sofia, Bulgaria; \\ mmp@mail.bg (M.P.); mpesevska93@gmail.com (M.P.-S.); panayotovagaby@abv.bg (G.P.) \\ 2 Department of Clinical Immunology, Medical Faculty, University Hospital Lozenetz, Sofia University, \\ St. Kliment Ohridski, 1407 Sofia, Bulgaria \\ * Correspondence: tsvelikova@medfac.mu-sofia.bg
}

check for

updates

Citation: Peruhova, M.;

Peshevska-Sekulovska, M.;

Panayotova, G.; Velikova, T. Foremost

Concepts in Mechanisms of De Novo

Post-Liver Transplantation

Malignancy. Gastroenterol. Insights

2021, 12, 283-292. https://doi.org/

t10.3390/gastroent12030025

Academic Editor: Jean-Francois

H. Geschwind

Received: 9 May 2021

Accepted: 21 June 2021

Published: 23 June 2021

Publisher's Note: MDPI stays neutral with regard to jurisdictional claims in published maps and institutional affiliations.

Copyright: (c) 2021 by the authors. Licensee MDPI, Basel, Switzerland. This article is an open access article distributed under the terms and conditions of the Creative Commons Attribution (CC BY) license (https:// creativecommons.org/licenses/by/ $4.0 /)$

\begin{abstract}
In liver transplant patients, solid tumors and post-transplant lymphoproliferative disorders (PTLD) have emerged as significant long-term mortality causes. Additionally, it is assumed that de novo malignancy (DNM) after liver transplantation (LT) is the second-leading cause of death after cardiovascular complications. Well-established risk factors for PTLD and solid tumors are calcineurin inhibitors (CNIs), tacrolimus (TAC), and cyclosporine, the cornerstones of all immunosuppressive (IS) therapies used after LT. The loss of immunocompetence facilitated by the host immune system due to prolonged IS therapy leads to cancer development, including in LT patients. Hindering DNA repair mechanisms, promoting tumor cell invasiveness, and hampering apoptosis are critical events in tumorigenesis and tumor growth in LT patients resulting from IS administration. This paper aims to overview the refined mechanisms of IS-induced tumorigenesis after LT and the loss of immunocompetence facilitated by the host immune system due to prolonged IS therapy. In addition, we also discuss in detail the mechanisms of action in different types of IS regimen used after LT, and their putative effect on DNM.
\end{abstract}

Keywords: liver transplantation; de novo malignancy; immunosuppressive therapy; calcineurin inhibitors; tacrolimus; cyclosporine; carcinogenesis; immune tolerance

\section{Introduction}

Liver transplantation (LT) is the treatment of choice for patients with end-stage liver disease, such as decompensated liver disease, cirrhosis, acute hepatic failure, and hepatocellular cancer [1]. However, the mortality rate after LT remains high. Still, the primary causes of mortality during the early post-transplantation period are infections and surgical complications [2]. Additionally, in liver transplant patients, solid tumors and post-transplant lymphoproliferative disorders (PTLD) have emerged as significant long-term causes of death [3]. Furthermore, it was estimated that liver transplant recipients have a higher risk of developing de novo malignancy (DNM) compared to the general population, with standardized incidence ratios (SIRs) ranging from 2.3 to 4.3 [4,5]. Besides, it is assumed that DNM after LT, especially for smoking-induced cancers (i.e., head and neck, lung, and esophageal), and virus-induced cancers (i.e., cervical and Kaposi's sarcoma), is the second-leading cause of death after cardiovascular complications [6].

We have to emphasize that the liver is the only solid organ in which malignancy could be an indication for transplantation; thus, cancer recurrence after LT could be a possible scenario. DNM and recurrence malignancy after LT make this topic very complex and significant. Moreover, well-established risk factors for PTLD and solid tumors are calcineurin inhibitors (CNIs), tacrolimus (TAC), and cyclosporine, the cornerstones of all immunosuppressive therapies used after LT [7]. In 1981, cyclosporine was introduced in the post-LT period as a new immunosuppression (IS) drug. This event was remarkable in 
the history of LT. Nowadays, the IS regimen improvement is one of the most critical factors leading to long-term survival and favorable outcome in patients after LT [8,9].

However, on the one hand, the crucial effect of IS agents leads to a significant reduction in steroid-resistant rejection rates and rejection-related graft loss [10]. On the other hand, more prolonged patient survival after LT is correlated with prolonged exposure to IS. Since such long-time therapy with IS is associated with unwanted adverse events, it is considered a double-edged sword [11]. In line with this, to prevent adverse effects, especially those related to DNM, an optimal IS regimen plays a central role in long-term survival in patients after LT.

This paper aims to overview the refined mechanisms of IS-induced tumorigenesis after LT and the loss of immunocompetence facilitated by the host immune system due to prolonged IS therapy. In addition, we also discuss in detail the mechanisms of action in different types of IS regimen used after LT and their putative effect on DNM.

\section{De Novo Malignancy in Patients after Liver Transplantation}

Risk factors such as aging and lifestyle of recipients, sun exposure, alcohol, and tobacco consumption before and after LT are strongly associated with the development of DNM in these patients. Other important events, such as decreased immune surveillance, activation of oncogenic viruses, and direct impact of certain classes of IS therapy, play a pivotal role in tumorigenesis after LT [12]. It has been reported that the overall incidence of DNM in LT ranges from 3.1 to $14.4 \%$, depending on the period of the study and duration of IS treatment $[3,13]$.

A large study by Altieri et al., including 1480 recipients, elucidated the most significant risk factors leading to DNM after LT. The authors demonstrated that recipient age, male gender, deceased donor, and the type of the initial liver disease are the most critical causes of post-LT DNM [14]. The most common malignancy after LT is non-melanoma skin cancers, but they do not affect patient survival. More interestingly, in alcohol consumers and long-time smokers, the risk of developing DNM increases significantly due to induced DNA damage $[15,16]$.

A great diversity of epidemiological data came from different registry databases or single-center retrospective studies. However, reliable numbers related to the incidence of DNM after LT were obtained. Although some reports announce PTLD with the highest frequency, other sources outline non-melanoma skin cancer as the most common. Table 1 presents estimated SIRs for the incidence of DNM in LT recipients according to the reviews by Sherston et al. and Shalaby et al. [12,17].

Table 1. Estimated standard incidence ratio for each malignancy after LT (adapted from Sherston et al. and Shalaby et al.) [12,17].

\begin{tabular}{cc}
\hline Cancer Type & SIR \\
\hline Kaposi's sarcoma & $61.46-100$ \\
\hline Skin (non-melanoma) & $>13.85$ \\
\hline Head and neck cancers & $2.5-24.8$ \\
\hline PTLD & $3.9-21$ \\
\hline Thyroid & $0.65-4.6$ \\
\hline Esophagus & $12-23.4$ \\
\hline Stomach & $0.5-3.7$ \\
\hline Pancreas and biliary tract & $1.1-6.4$ \\
\hline Colorectal overall & $1.24-12.5$ \\
\hline Colorectal in IBD/PSC & $3-5$ \\
\hline
\end{tabular}


Table 1. Cont.

\begin{tabular}{cc}
\hline Cancer Type & SIR \\
\hline Colorectal in non-IBD/PSC & $1-1.8$ \\
\hline Anal cancer & $3.3-10$ \\
\hline Lung, trachea, and bronchus & $1.1-8$ \\
\hline Urological tract & $0.8-10.2$ \\
\hline Kidney & $1.8-30$ \\
\hline Prostate (in males) & $0.39-2.2$ \\
\hline Cervix (in females) & $1.03-30.7$ \\
\hline Vulva (in females) & $8-23.8$ \\
\hline Breast (in females) & $0.3-2.3$ \\
\hline
\end{tabular}

SIR—standardized incidence ratio.

\section{Immunosuppression and Carcinogenesis}

To elucidate the impact of IS on carcinogenesis after LT, we have to pay attention to the different immune mechanisms involved in preventing cancer development. The term "immunoediting" describes a process wherein the immune system remodels tumor immunogenicity and represses tumorigenesis. Immunoediting has three component phases: elimination, equilibrium, and escape [18]. These tumor cells, which successfully pass this process, might prevent their destruction by the host's immune system.

Furthermore, these cells have the ability to outsmart the immune system; thereby, they might start uncontrollable promotion of tumor burden. The first phase of "elimination" is characterized by the immune system's ability to recognize and eliminate modified cells by distinct immune system mechanisms [19]. It is assumed that a growing tumor mass is a factor that initiates this process by recruiting macrophages, dendritic cells, and infiltrating lymphocytes (natural killer (NK) cells and NK T cells that release interferon-gamma, INF$\gamma$ ). The latter is the main cytokine that activates the release of chemokines (e.g., CXCL9, CXCL10, and CXCL11), aiming to suppress tumor angiogenesis and to induce tumor cells' apoptosis or programmed cell death (PCD) type I. Tumor-specific dendritic cells facilitate the cytotoxic T cells (CD8+), which infiltrate the tumor after recognition of tumorassociated antigens. This process further activates other immune mechanisms to help $\mathrm{B}$ cells to produce specific antibodies.

When the tumor cells bypass the elimination phase of the immune system, the equilibrium phase starts. This phase is characterized by lymphocytes' ability to recognize genetically unstable and mutated tumor cells and prevent tumor expansion. In the third phase of "immunoediting," the tumor cells evade the immune system and, in an uncontrolled manner, might cause malignant transformation and direct transfer to the escape phase [20-22].

Additionally, different types of nonimmune surveillance mechanisms against tumors exist, such as genetic, intra- and intercellular, and epigenetic surveillance. For example, genetic surveillance is based on DNA repair and checkpoint control of the cell cycle. In contrast, intracellular mechanisms include apoptosis or type I PCD, and intercellular mechanisms are associated with tumor microenvironment factors. Additionally, epigenetic surveillance is a compound process of gene regulation by changing chromatin architecture, influenced by different transcription factors [23,24].

All of the above-described mechanisms, which the immune system employs to control tumors, may be disturbed by the IS modalities, leading to cancer development, including in LT patients. 


\section{Immunosuppressive Drugs and Their Impact on the Immune System Tumor Control}

As organ transplant recipients, liver transplant patients often receive a combination of two or more IS agents to prevent allograft rejection. Nowadays, IS agents are used after LT, including cyclosporine, TAC, sirolimus, MMF, basiliximab, and corticosteroids.

\subsection{Corticosteroids after $L T$}

Nowadays, a significant percentage of patients after LT receive corticosteroids in combinations with other IS agents. These drugs are commonly used for IS induction and are considered first-line agents to treat acute rejection [25]. Corticosteroids are a class of nonspecific anti-inflammatory drugs, which interfere with the cytokine gene transcription. Since they hamper T cells' activation, corticosteroids decrease the inflammatory response by inhibiting pro-inflammatory cytokines such as IL-1, IL-2, IL-6, etc. This process is performed by inhibiting the nuclear translocation of transcription factors, such as nuclear factor- $\mathrm{kB}$, after binding to glucocorticoid receptors in the cytoplasm [26]. However, it was recently shown that many transplant centers prefer steroid-free IS regimens because of the tremendous number of steroid-related adverse events [27].

Additionally, there are insufficient data regarding steroid regimens and the development of DNM after LT because of the heterogeneity in dosage and different immunosuppressive protocols between centers. For this reason, it is difficult to obtain a reliable analysis of pooled data. So far, there is no evidence suggesting that corticosteroids do not directly influence the risk of DNM development after LT [25]. Furthermore, it is well known that corticosteroids increase tumor cell resistance in solid tumors by disarming $\mathrm{B}$ and T lymphocytes, decrease expression of major histocompatibility class I antigen in vivo, and reduce immunosurveillance [28]. It was also demonstrated that corticosteroids could modulate the process of immunosurveillance and promote anti-apoptotic and proliferative effects in various cell types. For that reason, they possibly contribute to the increased risk of DNM in organ transplant recipients. However, further studies have to be conducted to prove the relationship between the potential contribution of corticosteroids and the risk of cancer development in transplanted patients. This task is further tricky because corticosteroids are always administered in combination with other IS agents after LT [29].

\subsection{Tacrolimus after $L T$}

In standard patients after LT, the first choice of IS, based on CNI, is often TAC, whereas cyclosporine could be optional [30]. The immunosuppressive mechanism of TAC is described in detail below (Figure 1). TAC attaches to immunophilin TAC-binding protein in the T-cell cytoplasm. Afterwards, this complex is bound to the calcineurin enzyme. As a consequence of this action, dephosphorylation of the cytoplasmic component of the nuclear factor (NF) is prevented; thus, the transfer of NF into the nucleus is blocked, and binding to the IL-2 gene does not occur. Additionally, the production of IL-2 is interrupted, which is vital for T-cell activation [31]. IL-2 is a well-known cytokine that plays a significant role in communication between different immune cells and is essential for their activation [32]. After binding to the IL-2 receptor, which has three subunits (IL-2R $\alpha$ (CD25), IL-2R $\beta$ (CD122), and IL-2R $\gamma$ (CD132)), the activation of many critical inflammatory cells is initiated. For instance, the expression of CD25 (IL-2R $\alpha$ ) leads to the activation and expansion of immunosuppressive regulatory $\mathrm{T}$ cells (Treg) [33]. 


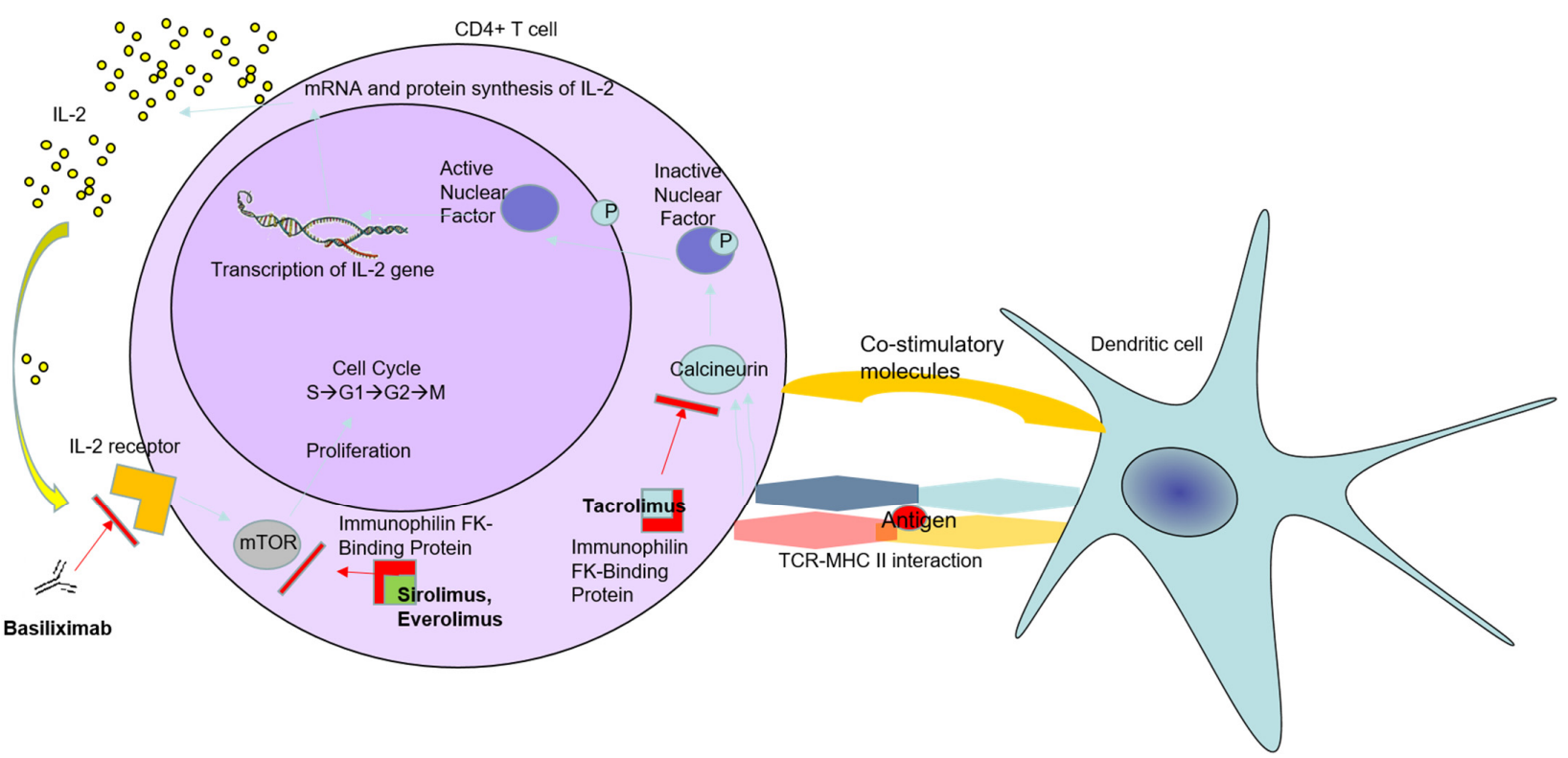

Figure 1. Mechanisms of action of tacrolimus, everolimus, and sirolimus. By attaching to immunophilin FK-binding protein and calcineurin enzyme in the T-cell cytoplasm, tacrolimus prevents the nuclear factor's dephosphorylation and transportation into the nucleus. Therefore, the synthesis of interleukin-2 (IL-2) is blocked, leading to interrupted T-cell activation. Basiliximab, a chimeric mouse-human monoclonal antibody that binds to the IL-2 receptor (a.k.a., CD25), is another approach to block T-cell activation after liver transplantation. mTOR inhibitors such as everolimus and sirolimus, act as interrupting mTOR actions (e.g., regulating protein expression, cell proliferation, and survival). However, the mTORC2 complex may promote liver tumorigenesis by direct phosphorylation of the protein kinase Akt, essential for actin cytoskeleton regulation.

A study by Angriman et al. demonstrated that a reduced Treg subpopulation in mice receiving TAC, cyclosporine, and mTOR inhibitors correlated with the reduced protumorigenic effect of these cells [34]. High expression of IL-2R $\beta$ and IL-2R $\gamma$ was detected in NK cells, monocytes, macrophages, and resting CD4+ and resting CD8+ T cells. The latter could distinguish tumor cells and exert antitumor cytotoxicity [35]. Considering all these data, the anticipated complications associated with prolonged IS after LT remain a significant issue. It was well established in many studies that chronic use of CNI leads to increased risk of renal dysfunction, neurotoxicity, metabolic disorders, and DNM [36,37].

Moreover, a correlation between $\mathrm{CNI}$ after LT and direct pro-oncogenic activity has been reported by different groups. Tumorigenesis and tumor growth in LT patients are thought to be linked with the length of IS therapy exposure and intensity [38].

Further analyses revealed that the delicate mechanisms in DNM tumorigenesis after LT are associated with processes such as hindering DNA repair mechanisms, promoting tumor cell invasiveness, and hampering apoptosis [39].

It is noteworthy that excessive angiogenesis plays a major role in tumor expansion, where CNI could maintain this tumor angiogenesis by stimulating vascular endothelial growth factor [40]. Another putative oncogenic pathway of CNI is associated with overexpression of the TGF $\beta 1$ gene, which leads to tumor cell invasion and promotion of metastatic potential. Therefore, more aggressive behavior and the earlier manifestation of an oncological disease have been observed in patients after LT [41,42].

CIN, and TAC, particularly, increase the possibility of developing new-onset diabetes mellitus after LT. In patients with severe diabetes, the alternative IS treatment option is monotherapy with cyclosporine. Approximately a quarter of patients after LT, who received TAC plus steroids, are suitable for this entity. It is well known that diabetes is a risk factor for developing various neoplasm types; notably, hepatocellular carcinoma (HCC) [43-45]. Carenco et al. published a study that demonstrated the impact of the quantitative level of CNI exposure and frequency of DNM. They estimated that the mean 
blood concentration and exposure period of TAC were major factors for developing DNM after LT [46].

Based on the presented data, clinicians' selection of proper IS treatment should be grounded in certain variables. Primary liver diseases, pre-LT patient status, co-morbidities, and surgical complications are among the crucial factors that impact the final IS treatment choice. A plethora of studies report the adverse effects associated with prolonged usage of CNI. Hence, strategies to reduce these adverse effects, including dose reduction or switching to another IS class, should be kept in mind by clinicians [30].

\subsection{Mycophenolate Mofetil after LT}

In the 1990s, mycophenolate mofetil (MMF) was introduced to LT management as an immunosuppressive agent. MMF is a prodrug compound of mycophenolic acid (MPA), a selective and reversible uncompetitive inhibitor of inosine monophosphate dehydrogenase (IMPDH) [47]. This pathway is crucial for the de novo synthesis of guanosine nucleotides, and it is well known that T and B lymphocytes are more dependent on this pathway than other cells [48]. Most of the IS guidelines recommend MMF as IS combined with another IS class, such as CNI or mTOR inhibitors. The IS regimens containing MMF allow a reduction in CNI-induced renal toxicity through maintaining the dosages of CNI [30]. Initially, MMF was used as an antineoplastic agent because of its ability to inhibit some tumor cell lines proliferation [49]. Furthermore, MMF exhibits its antitumor activity by interfering with the tumor growth and tumor cell adhesion to vascular endothelium [50].

A significant scientific challenge nowadays is defining whether MMF, as an IS agent after LT, provokes malignant transformation in the human body. So far, insufficient data related to the prooncogenic effect of MMF after LT have been published. Data from the Scientific Registry of Transplant Recipients indicate that MMF use in recipients of kidney grafts is correlated with a decreased risk of PTLD or any other malignancy [51].

An interesting study by Koehl et al. observed the potential of MMF in animal models to inhibit tumor cell expansion and tumor angiogenesis. The study results are controversial since MMF showed only a marginal effect on tumor growth [52]. However, these results correspond indirectly to the data mentioned above from the Scientific Registry of Transplant Recipients.

\subsection{Mammalian Target of Rapamycin (mTOR) Inhibitors after LT}

For the first time in clinical practice, mTOR inhibitors were used as anti-cancer drugs. Later, they found applications as IS agents for patients after kidney transplants. In LT recipients, mTOR inhibitors proved their efficacy in the prevention of immunologic rejection in organ transplantation. Nowadays, about $4 \%$ of patients after LT receive mTOR inhibitors as IS treatment combined with MMF [53]. The undoubted benefits from IS therapy with mTOR inhibitors are associated with reducing CNI-related nephrotoxicity, which is a wellknown adverse effect as a consequence of CNI-IS treatment. Another important reason for the implication of mTOR inhibitors in the post-transplant period is avoiding and/or postponing HCC recurrence in this patient population. Last but not least, usage of mTOR inhibitors leads to a reduction in the frequency of post-LT malignancies [54,55].

This IS class inhibits serine-threonine kinase, which belongs to the family of phosphatidylinositol-3 kinase (PI3K). It is thought to be involved in the cell cycle, cellular metabolism, and apoptosis $[56,57]$. The refined mechanisms of mTOR inhibitors include obstructing the cell cycle in the G1 phase, consequently hampering protein synthesis (Figure 1) [58]. This mTOR inhibitor's action is carried out by two protein complexes, mTORC1 and mTORC2. mTORC1, through phosphorylating different kinases, regulates the expression of proteins that interfere with cell proliferation and survival.

On the contrary, mTORC2 directly phosphorylates AKT (protein kinase B), therefore regulating the actin cytoskeleton and promoting liver tumorigenesis. It was established that mTORC1 is more sensitive to treatment with mTOR inhibitors than mTORC2, which is less sensitive to the drug [59]. As a general principle, mTOR inhibitors have many positive 
effects on patient outcomes and survival after LT. In contrast to the conventional IS drugs, mTOR inhibitors demonstrated a reduced incidence of DNM in high-risk LT patients while preventing immunologic rejection. Thus, mTOR inhibitors showed promising therapeutic results in patients with DNM because of their ability to decrease vascular endothelial growth factor synthesis and interrupt angiogenesis [40].

Additionally, the antitumor effect of mTOR inhibitors has been comprehensively reported in some studies, including in patients with HCC. It was established that progression and spreading in HCC depend on the mTOR signaling pathway involved in cell metabolism and proliferation. Notably, more aggressive tumor progression and shorter survival in patients with HCC were associated with a constitutively activated PI3K/AKT/mTOR pathway [60]. Therefore, the available data from the literature confirmed that mTOR inhibitors could be a feasible treatment option to limit HCC recurrence and progression in LT recipients [61-63].

In clinical practice after LT, two types of mTOR inhibitors find their application: sirolimus and everolimus. A study by Toso et al. proved that sirolimus-based IS showed significantly better outcomes for post-LT HCC patients [62]. Furthermore, another clinical study by Cholongitas et al., which included 3666 patients, showed the negative association between mTOR inhibitors and HCC recurrence after LT against patients on CNI therapy. The investigators estimated a significantly lower incidence of HCC recurrence in mTOR inhibitor patients than CNI-treated patients (448/3227 or $13.8 \%$ vs. $35 / 439$ or $8 \%, p<0.001$ ] [61]. Unfortunately, many clinical studies, especially retrospective ones, showed insufficient efficacy of mTOR inhibitors on HCC progression and recurrence after LT. Therefore, more studies have to be conducted to obtain a more efficient mTOR inhibitor dose, regimen, etc. [64].

Another beneficial aspect of mTOR inhibitors in clinical practice was documented in patients who developed DNM after LT. A retrospective study conducted by JimenezRomero et al. in 850 LT patients compared LT patients with DNM who were switched to sirolimus monotherapy and LT patients who received standard IS regimens with CNI/MMF. The authors showed that sirolimus monotherapy is effective and safe, which further improves survival outcomes in LT recipients with DNM [65].

Regarding the incidence of skin cancer after LT, Funk-Debleds et al. demonstrated that conversion from CNI-based regimen to mTOR inhibitors could reduce the development of non-melanoma skin cancer [66]. The implication of mTOR inhibitors in LT leads to some benefits in renal function compared to CNI. Particularly, everolimus, combined with MMF, could be a therapeutic tool in post-LT patients with signs of CNI-induced neuro-nephrotoxicity. Moreover, because of its protective cardiovascular effect, everolimus is recommended, especially in patients with diabetic nephropathy. Furthermore, the oncological benefits concerning switching LT patients with DNM from standard IS to sirolimus/everolimus have been proven. This alternative IS regimen could be a feasible long-term treatment option for LT patients.

\section{Conclusions}

The management of DNM after LT represents a serious challenge. The therapeutic options depend on the stage and type of cancer, interactions with IS agents, and the graft condition. Even though there are insufficient data about the correlation between IS treatment and carcinogenesis in LT recipients, many authors put forward the idea of a direct role of IS as a tumorigenesis-promoting factor. Therefore, reducing IS treatment after LT is of paramount importance for patients, aiming to prevent the development of DNM. Based on the presented data, the selection of proper IS treatment by clinicians should be grounded in certain variables. Primary liver diseases, pre-LT patient status, co-morbidities, and surgical complications are among the crucial factors that impact the final IS treatment choice. Hence, strategies to reduce adverse effects, including dose reduction or switching to another IS class, should be kept in mind by clinicians. 
Author Contributions: All authors wrote additional sections of the paper. All authors have read and agreed to the published version of the manuscript.

Funding: This research received no external funding.

Institutional Review Board Statement: Not applicable.

Informed Consent Statement: Not applicable.

Data Availability Statement: Not applicable.

Conflicts of Interest: The authors declare no conflict of interest.

\section{References}

1. Fox, A.N.; Brown, R.S., Jr. Is the patient a candidate for liver transplantation? Clin. Liver Dis. 2012, 16, 435-448. [CrossRef] [PubMed]

2. Adam, R.; Karam, V.; Delvart, V.; O'Grady, J.; Mirza, D.; Klempnauer, J.; Castaing, D.; Neuhaus, P.; Jamieson, N.; Salizzoni, M.; et al. Evolution of indications and results of liver transplantation in Europe. A report from the European Liver Transplant Registry (ELTR). J. Hepatol. 2012, 57, 675-688. [CrossRef]

3. $\quad$ Engels, E.A.; Pfeiffer, R.M.; Fraumeni, J.F., Jr.; Kasiske, B.L.; Israni, A.K.; Snyder, J.J.; Wolfe, R.A.; Goodrich, N.P.; Bayakly, A.R.; Clarke, C.A.; et al. Spectrum of cancer risk among US solid organ transplant recipients. JAMA 2011, 306, 1891-1901. [CrossRef] [PubMed]

4. Na, R.; Grulich, A.E.; Meagher, N.S.; McCaughan, G.W.; Keogh, A.M.; Vajdic, C.M. Comparison of de novo cancer incidence in Australian liver, heart and lung transplant recipients. Am. J. Transplant. 2013, 13, 174-183. [CrossRef]

5. Krynitz, B.; Edgren, G.; Lindelöf, B.; Baecklund, E.; Brattström, C.; Wilczek, H.; Smedby, K.E. Risk of skin cancer and other malignancies in kidney, liver, heart and lung transplant recipients 1970 to 2008-A Swedish population-based study. Int. J. Cancer 2013, 132, 1429-1438. [CrossRef]

6. Carenco, C.; Faure, S.; Ursic-Bedoya, J.; Herrero, A.; Pageaux, G.P. Solid, non-skin, post-liver transplant tumors: Key role of lifestyle and immunosuppression management. World J. Gastroenterol. 2016, 22, 427-434. [CrossRef]

7. Bakker, N.A.; van Imhoff, G.W.; Verschuuren, E.A.; van Son, W.J. Presentation and early detection of post-transplant lymphoproliferative disorder after solid organ transplantation. Transpl. Int. 2007, 20, 207-218. [CrossRef] [PubMed]

8. Scientific Registry Transplant Recipients (SRTR). Transplant Center Search Results. Available online: http://www.srtr.org (accessed on 28 June 2020).

9. European Liver Transplant Registry. Evolution of Liver Transplantation in Europe. Available online: http://www.eltr.org (accessed on 28 June 2020).

10. Adam, R.; McMaster, P.; O'Grady, J.G.; Castaing, D.; Klempnauer, J.L.; Jamieson, N.; Neuhaus, P.; Lerut, J.; Salizzoni, M.; Pollard, S.; et al. European Liver Transplant Association. Evolution of liver transplantation in Europe: Report of the European Liver Transplant Registry. Liver Transpl. 2003, 9, 1231-1243. [CrossRef]

11. Di Maira, T.; Coelho, L.E.; Berenguer, M. Immunosuppression in liver transplant. Best Pract. Res. Clin. Gastroenterol. 2020, 46-47, 101681. [CrossRef]

12. Sherston, S.N.; Carroll, R.P.; Harden, P.N.; Wood, K.J. Predictors of cancer risk in the long-term solid-organ transplant recipient. Transplantation 2014, 97, 605-611. [CrossRef] [PubMed]

13. Piselli, P.; Verdirosi, D.; Cimaglia, C.; Busnach, G.; Fratino, L.; Ettorre, G.M.; De Paoli, P.; Citterio, F.; Serraino, D. Epidemiology of de novo malignancies after solid-organ transplantation: Immunosuppression, infection and other risk factors. Best Pract. Res. Clin. Obstet. Gynaecol. 2014, 28, 1251-1265. [CrossRef]

14. Altieri, M.; Sérée, O.; Lobbedez, T.; Segol, P.; Abergel, A.; Blaizot, X.; Boillot, O.; Boudjema, K.; Coilly, A.; Conti, F.; et al. Risk factors of de novo malignancies after liver transplantation: A French national study on 11004 adult patients. Clin. Res. Hepatol. Gastroenterol. 2021, 45, 101514. [CrossRef]

15. Benlloch, S.; Berenguer, M.; Prieto, M.; Moreno, R.; San Juan, F.; Rayón, M.; Mir, J.; Segura, A.; Berenguer, J. De novo internal neoplasms after liver transplantation: Increased risk and aggressive behavior in recent years? Am. J. Transplant. 2004, 4, 596-604. [CrossRef]

16. Das, R.; Kundu, S.; Laskar, S.; Choudhury, Y.; Ghosh, S.K. Assessment of DNA repair susceptibility genes identified by wholeexome sequencing in head and neck cancer. DNA Repair. 2018, 66-67, 50-63. [CrossRef]

17. Shalaby, S.; Burra, P. De novo and recurrent malignancy. Best Pract. Res. Clin. Gastroenterol. 2020, 46-47, 101680. [CrossRef] [PubMed]

18. Prendergast, G.C. Immune escape as a fundamental trait of cancer: Focus on IDO. Oncogene 2008, 27, 3889-3900. [CrossRef] [PubMed]

19. Vajdic, C.M.; van Leeuwen, M.T. Cancer incidence and risk factors after solid organ transplantation. Int. J. Cancer 2009, 125, 1747-1754. [CrossRef] [PubMed]

20. Lake, R.A.; van der Most, R.G. A better way for a cancer cell to die. N. Engl. J. Med. 2006, 354, 2503-2504. [CrossRef] [PubMed] 
21. Zitvogel, L.; Tesniere, A.; Kroemer, G. Cancer despite immunosurveillance: Immunoselection and immunosubversion. Nat. Rev. Immunol. 2006, 6, 715-727. [CrossRef]

22. Dunn, G.P.; Koebel, C.M.; Schreiber, R.D. Interferons, immunity and cancer immunoediting. Nat. Rev. Immunol. 2006, 6, 836-848. [CrossRef]

23. Glick, A.B.; Yuspa, S.H. Tissue homeostasis and the control of the neoplastic phenotype in epithelial cancers. Semin. Cancer Biol. 2005, 15, 75-83. [CrossRef]

24. Ferro, M.; Ungaro, P.; Cimmino, A.; Lucarelli, G.; Busetto, G.M.; Cantiello, F.; Damiano, R.; Terracciano, D. Epigenetic Signature: A New Player as Predictor of Clinically Significant Prostate Cancer (PCa) in Patients on Active Surveillance (AS). Int. J. Mol. Sci. 2017, 18, 1146. [CrossRef] [PubMed]

25. Gutierrez-Dalmau, A.; Campistol, J.M. Immunosuppressive therapy and malignancy in organ transplant recipients: A systematic review. Drugs 2007, 67, 1167-1198. [CrossRef] [PubMed]

26. Conti, F.; Morelon, E.; Calmus, Y. Immunosuppressive therapy in liver transplantation. J. Hepatol. 2003, 39, 664-678. [CrossRef]

27. Haller, M.C.; Royuela, A.; Nagler, E.V.; Pascual, J.; Webster, A.C. Steroid avoidance or withdrawal for kidney transplant recipients. Cochrane Database Syst. Rev. 2016, 8, CD005632. [CrossRef]

28. Rutz, H.P.; Herr, I. Interference of glucocorticoids with apoptosis signaling and host-tumor interactions. Cancer Biol. Ther. 2004, 3, 715-718. [CrossRef]

29. Pelletier, S.J.; Nadig, S.N.; Lee, D.D.; Ammori, J.B.; Englesbe, M.J.; Sung, R.S.; Magee, J.C.; Fontana, R.J.; Punch, J.D. A prospective, randomized trial of complete avoidance of steroids in liver transplantation with follow-up of over 7 years. HPB 2013, 15, 286-293. [CrossRef]

30. Cillo, U.; De Carlism, L.; Del Gaudio, M.; De Simone, P.; Fagiuoli, S.; Lupo, F.; Tisone, G.; Volpes, R. Immunosuppressive regimens for adult liver transplant recipients in real-life practice: Consensus recommendations from an Italian Working Group. Hepatol. Int. 2020, 14, 930-943. [CrossRef]

31. Bennett, J.; Cassidy, H.; Slattery, C.; Ryan, M.P.; McMorrow, T. Tacrolimus Modulates TGF- $\beta$ Signaling to Induce EpithelialMesenchymal Transition in Human Renal Proximal Tubule Epithelial Cells. J. Clin. Med. 2016, 5, 50. [CrossRef]

32. Dougan, M.; Dranoff, G. Immune therapy for cancer. Annu. Rev. Immunol. 2009, 27, 83-117. [CrossRef]

33. Mortara, L.; Balza, E.; Bruno, A.; Poggi, A.; Orecchia, P.; Carnemolla, B. Anti-cancer Therapies Employing IL-2 Cytokine Tumor Targeting: Contribution of Innate, Adaptive and Immunosuppressive Cells in the Anti-tumor Efficacy. Front. Immunol. 2018, 9 , 2905. [CrossRef] [PubMed]

34. Angriman, I.; Furian, L.; Scarpa, M. Effects of immune suppression for transplantation on inflammatory colorectal cancer progression. Oncogenesis 2018, 7, 46. [CrossRef] [PubMed]

35. Spolski, R.; Li, P.; Leonard, W.J. Biology and regulation of IL-2: From molecular mechanisms to human therapy. Nat. Rev. Immunol. 2018, 18, 648-659. [CrossRef]

36. Burra, P.; Rodriguez-Castro, K.I. Neoplastic disease after liver transplantation: Focus on de novo neoplasms. World J. Gastroenterol. 2015, 21, 8753-8768. [CrossRef] [PubMed]

37. Pillai, A.A.; Levitsky, J. Overview of immunosuppression in liver transplantation. World J. Gastroenterol. 2009, 15, 4225-4233. [CrossRef] [PubMed]

38. Hojo, M.; Morimoto, T.; Maluccio, M.; Asano, T.; Morimoto, K.; Lagman, M.; Shimbo, T.; Suthanthiran, M. Cyclosporine induces cancer progression by a cell-autonomous mechanism. Nature 1999, 397, 530-534. [CrossRef] [PubMed]

39. Yarosh, D.B.; Pena, A.V.; Nay, S.L.; Canning, M.T.; Brown, D.A. Calcineurin inhibitors decrease DNA repair and apoptosis in human keratinocytes following ultraviolet B irradiation. J. Investig. Dermatol. 2005, 125, 1020-1025. [CrossRef] [PubMed]

40. Guba, M.; von Breitenbuch, P.; Steinbauer, M.; Koehl, G.; Flegel, S.; Hornung, M.; Bruns, C.J.; Zuelke, C.; Farkas, S.; Anthuber, M.; et al. Rapamycin inhibits primary and metastatic tumor growth by antiangiogenesis: Involvement of vascular endothelial growth factor. Nat. Med. 2002, 8, 128-135. [CrossRef]

41. Maluccio, M.; Sharma, V.; Lagman, M.; Vyas, S.; Yang, H.; Li, B.; Suthanthiran, M. Tacrolimus enhances transforming growth factorbeta1 expression and promotes tumor progression. Transplantation 2003, 76, 597-602. [CrossRef]

42. Verran, D.J.; Mulhearn, M.H.; Dilworth, P.J.; Balderson, G.A.; Munn, S.; Chen, J.W.; Fink, M.A.; Crawford, M.D.; McCaughan, G.W. Nature and outcomes of the increased incidence of colorectal malignancy after liver transplantation in Australasia. Med. J. Aust. 2013, 199, 610-612. [CrossRef]

43. Soleimanpour, S.A.; Crutchlow, M.F.; Ferrari, A.M.; Raum, J.C.; Groff, D.N.; Rankin, M.M.; Liu, C.; De León, D.D.; Naji, A.; Kushner, J.A.; et al. Calcineurin signaling regulates human islet \{beta\}-cell survival. J. Biol. Chem. 2010, 285, 40050-40059. [CrossRef]

44. Levy, G.; Villamil, F.; Samuel, D.; Sanjuan, F.; Grazi, G.L.; Wu, Y.; Marotta, P.; Boillot, O.; Muehlbacher, F.; Klintmalm, G.; et al. Results of lis2t, a multicenter, randomized study comparing cyclosporine microemulsion with $\mathrm{C} 2$ monitoring and tacrolimus with C0 monitoring in de novo liver transplantation. Transplantation 2004, 77, 1632-1638. [CrossRef] [PubMed]

45. El-Serag, H.B.; Hampel, H.; Javadi, F. The association between diabetes and hepatocellular carcinoma: A systematic review of epidemiologic evidence. Clin. Gastroenterol. Hepatol. 2006, 4, 369-380. [CrossRef]

46. Carenco, C.; Assenat, E.; Faure, S.; Duny, Y.; Danan, G.; Bismuth, M.; Herrero, A.; Jung, B.; Ursic-Bedoya, J.; Jaber, S.; et al. Tacrolimus and the risk of solid cancers after liver transplant: A dose effect relationship. Am. J. Transplant. 2015, 15, 678-686. [CrossRef] [PubMed] 
47. Allison, A.C.; Eugui, E.M. Mycophenolate mofetil and its mechanisms of action. Immunopharmacology 2000, 47, 85-118. [CrossRef]

48. Cohn, R.G.; Mirkovich, A.; Caulfield, J.; Eugui, E.M. Apoptosis of human activated peripheral T-cells and Tlymphocytic and promonocytic cell lines induced by mycophenolic acid, the active metabolite of CellCept. In Proceedings of the Basic Sciences Symposium of the Transplantation Society, Monterey, CA, USA, 25-29 August 1999; p. 173.

49. Carter, S.B.; Franklin, T.J.; Jones, D.F.; Leonard, B.J.; Mills, S.D.; Turner, R.W.; Turner, W.B. Mycophenolic acid: An anti-cancer compound with unusual properties. Nature 1969, 223, 848-850. [CrossRef] [PubMed]

50. Engl, T.; Makarević, J.; Relja, B.; Natsheh, I.; Müller, I.; Beecken, W.D.; Jonas, D.; Blaheta, R.A. Mycophenolate mofetil modulates adhesion receptors of the beta1 integrin family on tumor cells: Impact on tumor recurrence and malignancy. BMC Cancer 2005, 5, 4. [CrossRef]

51. Francis, A.; Johnson, D.W.; Craig, J.; Teixeira-Pinto, A.; Wong, G. Post-transplant lymphoproliferative disease may be an adverse risk factor for patient survival but not graft loss in kidney transplant recipients. Kidney Int. 2018, 94, 809-817. [CrossRef]

52. Koehl, G.E.; Wagner, F.; Stoeltzing, O.; Lang, S.A.; Steinbauer, M.; Schlitt, H.J.; Geissler, E.K. Mycophenolate mofetil inhibits tumor growth and angiogenesis in vitro but has variable antitumor effects in vivo, possibly related to bioavailability. Transplantation 2007, 83, 607-614. [CrossRef]

53. De Simone, P.; Fagiuoli, S.; Cescon, M.; De Carlis, L.; Tisone, G.; Volpes, R.; Cillo, U.; Consensus Panel. Use of Everolimus in Liver Transplantation: Recommendations from a Working Group. Transplantation 2017, 101, 239-251. [CrossRef]

54. Sharma, P.; Welch, K.; Eikstadt, R.; Marrero, J.A.; Fontana, R.J.; Lok, A.S. Renal outcomes after liver transplantation in the model for end-stage liver disease era. Liver Transpl. 2009, 15, 1142-1148. [CrossRef] [PubMed]

55. Duvoux, C.; Toso, C. mTOR inhibitor therapy: Does it prevent HCC recurrence after liver transplantation? Transplant. Rev. 2015, 29, 168-174. [CrossRef]

56. Jacinto, E.; Hall, M.N. Tor signalling in bugs, brain and brawn. Nat. Rev. Mol. Cell Biol. 2003, 4, 117-126. [CrossRef] [PubMed]

57. Granata, S.; Dalla, G.A.; Carraro, A.; Brunelli, M.; Stallone, G.; Lupo, A.; Zaza, G. Sirolimus and Everolimus Pathway: Reviewing Candidate Genes Influencing Their Intracellular Effects. Int. J. Mol. Sci. 2016, 17, 735. [CrossRef] [PubMed]

58. Laplante, M.; Sabatini, D.M. mTOR signaling in growth control and disease. Cell 2012, 149, 274-293. [CrossRef]

59. Yang, H.; Rudge, D.G.; Koos, J.D.; Vaidialingam, B.; Yang, H.J.; Pavletich, N.P. mTOR kinase structure, mechanism and regulation. Nature 2013, 497, 217-223. [CrossRef]

60. Hu, T.H.; Huang, C.C.; Lin, P.R.; Chang, H.W.; Ger, L.P.; Lin, Y.W.; Changchien, C.S.; Lee, C.M.; Tai, M.H. Expression and prognostic role of tumor suppressor gene PTEN/MMAC1/TEP1 in hepatocellular carcinoma. Cancer 2003, 97, 1929-1940. [CrossRef]

61. Cholongitas, E.; Mamou, C.; Rodríguez-Castro, K.I.; Burra, P. Mammalian target of rapamycin inhibitors are associated with lower rates of hepatocellular carcinoma recurrence after liver transplantation: A systematic review. Transpl. Int. 2014, 27, 1039-1049. [CrossRef]

62. Toso, C.; Merani, S.; Bigam, D.L.; Shapiro, A.M.; Kneteman, N.M. Sirolimus-based immunosuppression is associated with increased survival after liver transplantation for hepatocellular carcinoma. Hepatology 2010, 51, 1237-1243. [CrossRef]

63. Treiber, G. mTOR inhibitors for hepatocellular cancer: A forward-moving target. Expert Rev. Anticancer Ther. $2009,9,247-261$. [CrossRef]

64. Ferrín, G.; Guerrero, M.; Amado, V.; Rodríguez-Perálvarez, M.; De la Mata, M. Activation of mTOR Signaling Pathway in Hepatocellular Carcinoma. Int. J. Mol. Sci. 2020, 21, 1266. [CrossRef] [PubMed]

65. Jiménez-Romero, C.; Manrique, A.; Marqués, E.; Calvo, J.; Sesma, A.G.; Cambra, F.; Abradelo, M.; Sterup, R.M.; Olivares, S.; Justo, I.; et al. Switching to sirolimus monotherapy for de novo tumors after liver transplantation. A preliminary experience. Hepatogastroenterology 2011, 58, 115-121. [PubMed]

66. Funk-Debleds, P.; Ducroux, E.; Guillaud, O.; Ursic-Bedoya, J.; Decullier, E.; Vallin, M.; Euvrard, S.; Pageaux, G.P.; Boillot, O.; Dumortier, J. Subsequent nonmelanoma skin cancers and impact of immunosuppression in liver transplant recipients. J. Am. Acad. Dermatol. 2018, 79, 84-91. [CrossRef] [PubMed] 